\title{
The meaning of Successful Aging in Javanese Elderly
}

\author{
${ }^{1}$ Christiana Hari Soetjiningsih, Dewi Agri Ralampi ${ }^{2}$, Sepriany V. Simatauw ${ }^{3}$ \\ soetji_25@yahoo.co.id, ralampiagri@gmail.com, rianysheva@gmail.com \\ ${ }^{1,2,3}$ Faculty of Psychology, Universitas Kristen Satya Wacana
}

\begin{abstract}
The achievement of successful aging (SA) is very important for elderly. SA aging as defined by Rowe and Kahn, encompasses the following components: low probability of disease, maintenance of physical and cognitive health, and active social engagement. The concept of SA will vary from culture to culture, because it is shaped by the norms and values of each society. However, until recently, there has been very little known about SA in Indonesia, especially in Javanese elderly. The aim of this study was to discover the meaning of SA among Javanese elderly. The data were collected from Central Java (Salatiga, Magelang, Solo, Semarang, Tegal, Pekalongan) and participants consisted of 50 Javanese elderly between 65-80 years old, obtained through purposive sampling. Research's data was collected by interview, observation, and documentation. The data was categorized, open coded, axial coded, and then analyzed descriptively. The findings revealed various dimensions of SA among participants, namely the family achievements, physical health, adequate finance, good relationship with others, and religious activity. Findings from this study can contribute to the development of interventions for Javanese elderly, in particular, and their families and the government to promote SA especially in Central Java.
\end{abstract}

Keywords: successful aging, Javanese elderly

\section{Introduction}

There are various opinions about the limitations of elderly age. Conventionally, "elderly" has been defined as a chronological age of 65 years old or older, while those from 65 through 74 years old are referred to as "early elderly" and those over 75 years old as "late elderly."[1]. According to $\mathrm{WHO}[2]$, the elderly group includes those aged 60 and above. In many countries, the elderly or older person are defined as having a chronological age of 65 years or older. The age limit of elderly in some developed countries such as the United States, Canada, the Netherlands, Australia, Sweden is 65 years and over because life expectancy in these countries is higher[3]. Based on the UU RI-Kesejahteraan Lanjut Usia[4], what is meant by elderly is someone who has reached the age of 60 (sixty) years and over. The process of growing old is a natural and natural thing that can happen to all individuals. But each individual can respond to changes that occur differently. Some feel anxious, afraid, or overly worried; but there are also those who accept it as a natural thing [5].

Regarding the condition of the elderly, until now there are still negative stereotypes about the elderly. The results of interviews about elderly conducted by the students of Faculty of Psychology Universitas Kristen Satya Wacana who participate in Psych gerontology courses, from year to 
year, and also in 2017[5] still tend to be the same. With subjects among children, adolescents and adults, generally shows there are still negative stereotypes about the condition of the elderly. Elderly people are described as individuals who are helpless, unattractive, easily sick, senile/forgetful, like children, talkative, rigid, unruly, sick, and other negative conditions. Such a view can have a bad effect on the development of the elderly because in addition to influencing the attitude of the elderly themselves about their condition also influences the way other people treat the elderly. As a result, the treatment given to the elderly is for example: not doing anything more and just resting. This treatment will cause the elderly to be passive because they are not allowed to do anything else, and it is detrimental because the treatment will affect the condition of the elderly and will tend to become a reality (self-fulfilling prophecy). In addition, negative views will also affect the elderly themselves that the condition of the elderly is a helpless condition; so that the elderly themselves are not eager to do anything else. This situation puts the elderly group as a minority group that is a status that in some cases excludes them from interacting with other groups, and only gives them little "power" in any case. Often too, the elderly are referred to as "second-class citizens" who live with defensive status. Such status can certainly have a negative effect on the person and the social adjustment of the elderly. This resulted in the final years of life of the elderly felt as an unhappy time. The elderly do not need anything but rest and prepare themselves for death. In fact, from various researches that have been conducted by experts and in fact, the elderly are actually not as expected so far. Elderly people can still do various things that benefit both themselves and their environment.

The old paradigm that considers the elderly as a burden, must now be removed. Because with the increasingly advanced field of health, technology, and other fields related to proven more and more elderly people are still healthy enough, able to work, and do things independently for themselves and benefit others[6]. Various recent studies have proven that elderly people do not experience a drastic decline as originally thought[2]. Changes that occur in the elderly are very individual, between one another and different. Indeed, in reality, not all elderly people are unable to do anything else because currently many elderly people are still able to carry out their obligations and activities that are beneficial to themselves and others/their environment. Elderly people can still do something that can be useful for themselves and others, even though within certain limits. So even though there are limitations, the elderly can still mean to others. According to Fries[6] that although the aging process weakens, but in his old age, individuals are still able to produce the richest moments of their lives. Fries believes that individuals have the capacity to enjoy age well, with elegance, wisdom, energy, and vitality. If changes in the old age are treated as a pressure, the effect tends to worsen the condition so that the negative image of the elderly as weak, unproductive and obnoxious individuals will continue to be borne by the elderly. But it is different if the elderly individual is able to adjust to these changes and undergo interventions, then his life will be better, namely in old age can still be effective, achieve self-actualization, live a happy and joyful life. Therefore, it is hoped that a better understanding, positive awareness and positive attitude will be grown both for the elderly themselves and their environment about the condition of the elderly so that there is appropriate treatment for the elderly.

In this case, of course, it is expected that the elderly can not only achieve longevity but more importantly are long-lived, healthy, happy, and can still benefit others. Moreover, in the future the 
number of elderly people around the world will increase more and more, so that this elderly group must not be a burden for both the family and the community, but still be able to participate in all areas of life according to their interests even though their productivity may not be as big as they were young. Thus the elderly can always be active and productive, which in other words achieve successful aging. In general, successful aging is understood as the process of being a good or successful old person. Achieving successful aging is very important for the elderly because currently the number of elderly people is increasing throughout the world including in Indonesia. Efforts to achieve old age with a healthy, happy, still able to work and benefit others seems not to be impossible at this time. In order to be optimally realized, the efforts that should be carried out must be started early and continue to be carried out in the following ages, even until the individual has an elderly period.

Various reports indicate that the number of elderly people around the world is increasing sharply because human life expectancy is increasing. Life expectancy of the population is the average chance or life time remaining. Life expectancy can also be interpreted as the number of years that people who live to a certain age are taken up. The size of the elderly population in the future will certainly have an impact, both positive and negative. Positive impact, if the elderly population is in a healthy, active and productive condition so that it does not become a burden for the family, the environment and the country. But on the other hand, it can be a burden for the family, the environment, the community, and the country if the elderly have health problems and the quality of psychic and social abilities that result in inability to move and increase health costs, decreased income / income, helplessness, decreased mental health conditions and the inability to work again.

World population data estimates that between 2015 and 2030 the population growth rate is 60 years and over or elderly by $56 \%$ from 901 million to 1.4 billion. In Indonesia, based on population projection data, the number of elderly population is also predicted to continue to increase. Data in 2017 shows that there are 23.66 million elderly people in Indonesia (9.03\%). Furthermore, it is predicted that the elderly population in 2020 (27.08 million), in 2025 (33.69 million), in 2030 (40.95 million). Until 2035, the number could reach around 48.2 million people from a total of 305.7 million people[7]. So it can be said, currently the elderly population in the world as well as in Indonesia are heading towards an old structured population. A country is said to be an aging population if it has an elderly population above seven percent. This condition which raises the issue of bonus demography is already in sight and has even begun to be experienced. The explosion in the population of productive age between 15 and 64 years will indirectly increase the percentage of elderly people who, if they fail, are anticipated to have an impact on various problems in various fields. Data from[8] shows that indeed not all provinces in Indonesia have an old structure. There were $19(55.88 \%)$ provinces of Indonesia that had an old population structure, namely three provinces with the largest percentage of elderly people bein, DI Yogyakarta (13.81\%), Central Java (12.59) and East Java (12.25\%). The largest increase in the number of elderly people is in developing countries, where now humans can live up to an average of 68 years and are expected to live to age 74 in 2050 . The life expectancy in developed countries is 78 years, at where a newborn child is now expected to live to be 83 years old. (https://www.voaindonesia.com/a/pbb). 
The increase in life expectancy has an impact on the emergence of various challenges that if able to face will have a positive impact. The elderly population also means an increase in demands for, among others, income security and long-term health and care services, which creates great psycho-socio-economic challenges, which must be answered through appropriate programs or policies. Therefore, the challenge that must be looked for a solution is how to empower individuals who are elderly and prepare the elderly group to be ready to face the old age well or achieve a condition of "successful aging". In Indonesia, various efforts have begun, for example in the health sector, the existence of a health insurance program by the BPJS has benefited the Indonesian population including the elderly to improve the quality of their health. Also BKKBN through the Bina Ketahanan Keluarga Lansia has sought to improve the quality of the elderly population

Other empowerment efforts still need to be sought and programmed appropriately because the empowerment of the elderly does not only cover physical aspects, but must comprehensively cover various aspects of physical, psychological, socio-emotional, and spiritual aspects. But before that it is necessary to know what the elderly think about successful aging because of the possibility of certain values possessed by the elderly that influence their opinion about successful old age[9] have already studied about seniors adults' conceptions of successful aging. Their qualitative study examined the perceptions of 18 senior adults about successful aging and findings indicated that successful aging involves engaging with others; coping with changes; and maintaining physical, mental, and financial health. Based on surveys about successful aging administered to 53 older adults in New Jersey, Ferri, James, and Pruchno[10] report there is no standard method for measuring successful aging or consensus on its definition. Participants defined successful aging as including activity /exercise (56\% of responses), physical health (46\%), social relationships (41\%), and psychological/cognitive health (33\%). Successful aging, as assessed by one question, is positively related to social support, life satisfaction, and subjective health. Some researchers state that cultural values or local wisdom values are one of the factors that influence successful aging. Tam[11] states that cultural values affect the perception of the elderly about successful aging. Previous studies on Indonesian elderly have been done quite a lot, but more partially, for example the research of Nugraheni and Soetjiningsih[3] related to the experience of loneliness in the elderly in the emptynest period. Then Novitasari and Soetjiningsih[3] explored the loneliness of elderly people whom living with family members. Furthermore Riandana and Soetjiningsih[12] examined the correlation family social support and psychological well-being in the elderly. However, many related to successful aging have not been widely carried out, especially successful aging in Javanese elderly.

Indonesia consists of various ethnic groups, each ethnic has its own cultural values or local wisdom, therefore this research wants to explore the meaning or opinion of successful aging among in the Javanese elderly and restricted Javanese elderly who live in the province of Central Java. Because the province of Central Java has many districts /cities, six cities in Central Java are determined, namely Salatiga, Solo, Magelang, Semarang, Tegal and Pekalongan. In addition, from the observation conducted by the research team, it was found that there were various conditions of the elderly, therefore in order for the study to be more in-depth, the elderly who excavated the data included the elderly who lived at home with their chlidren, the elderly who lived alone at homes (not with their children), elderly people who live in nursing homes, and elderly people from low 
socioeconomic status who are still working for a living. This research is a preliminary study which then results of the research obtained will be used as a basis for subsequent research which aims to develop an empowerment model to achieve successful aging in the elderly with the ecological approach of Bronfenbrenner. Through this perspective, Bronfenbrenner[13] states that individuals are beings who develop and adapt through interaction with all elements of the environment that surround their lives. So both individual characteristics and the environment through an interactive process play a role in individual development., so it's very important to know the meaning of successful aging in the Javanese elderly. Based on the background that has been stated, the formulation of the research problem in this study is what is the meaning of successful aging in the Javanese elderly?

\section{Literature Review}

The term "successful aging" has been used in the gerontological literature to cover processes of aging throughout the life span.The term "successful aging" suggests "key ideas such as life satisfaction, longevity, freedom from disability, mastery and growth, active engagement with life, and independence." Sometimes successful aging has been called "vital aging" or "active aging" or "productive aging" with the implication that later life can be a time of sustained health and vitality where older people contribute to society rather than merely a time of ill health and dependency[14].

There are various expert opinions about the concept of successful aging. Likewise in each elderly can have different opinions because of how people feel successful influenced by his background, life experience, and cultural values, etc. In general successful aging is understood as the process of being a good or successful old person, or something good and expected[15],[16] explain that successful aging is a combination of biological functions (health and immune system), psychological functions (mental health) and positive aspects of a person as a human (social competence, self-control, and satisfaction life). Rowe and Kahn[17] explain successful aging as the ability to manage three key characteristics or behaviors. The first is minimizing the risk of the emergence of various diseases and the effects associated with the disease, secondly is managing well the physical and psychological functions, and the third is the active involvement with life. These three factors are interconnected with one another in forming successful aging.

Components of Successful Aging according to Rowe and Kahn [17]namely:

1. Low probability of disease and disability. Low probability of disease refers not only to absence or presence of disease itself, but also to absence, presence, or severity of risk factors for disease. Elderly people have a small / low chance of contracting an illness. So it is not only about the existence or absence of an illness in the elderly, but more than that is how the elderly are able to move away from the factors that cause the risk of developing a disease in themselves. This is related to internal factors, namely how the elderly have an awareness of the positive lifestyle that must be lived. In addition, senior citizens also maintain their physical and mental health conditions. Also related to external factors that are related to the environment such as family, 
health workers, clergy, institutions, and government policies. So it must involve all elements because the health of the elderly is a shared responsibility and held in a holistic health system.

2. High cognitive and physical functional. High functional level includes both physical and cognitive components. Physical and cognitive capacities are potentials for activity; they tell us what a person can do, not what he or she does do. Even though there were various changes in the elderly, successful elderly people were able to maintain their physical and cognitive functioning. Factors that can influence must be minimized by making efforts such as physical activity that supports health and keeps adding knowledge / skills and maintaining memory.

3. Active engagement with life. While active engagement with life takes many forms, we are most concerned with two - interpersonal relations and productive activity. Interpersonal relations involve contacts and transactions with others, exchange of information, emotional support, and direct assistance. An activity is productive if it creates societal value, whether or not it is reimbursed. Thus, a person who cares for a disabled family member or works as a volunteer in a local church or hospital is being productive, although unpaid In this case the elderly must continue to establish social relations with their environment and also remain productive. For this, the elderly must continue to follow social activities in their environment or those carried out by certain organizations. The important relation that must be owned by the elderly is the existence of socio-emotional support and instrumental support which includes giving assistance to others directly or engaging in activities that benefit others.

Positive spirituality.[18] developed an enhanced model of successful aging based on Rowe and Kahn's theoretical framework. Evidence presented suggest that the addition of spirituality to interventions focused on health promotion has been received positively by older adults. Positive spirituality involves a developing and internalized personal relation with the sacred or transcendent that is not bound by race, ethnicity, economics, or class and promotes the wellness and welfare of self and others. Positive spirituality uses aspects of both religion and spirituality. Elderly has a good spirituality function that appears from having a sincere and sincere desire to improve the welfare of others and be able to reconcile and accept their own circumstances. If the elderly can maximize this function it will support achieving successful aging.

Crowther[18] argue that positive spirituality is the missing component in the model; it addresses the interrelatedness between the older adults' beliefs and values, the community, and the efficacy of interventions focused on successful aging. We maintain, with our broadened Rowe and Kahn model, that aging is multifaceted and consists of interdependent biological, psychological, social, and spiritual processes. Further, we assume that lives are lived within a social and historical context, and that the relation between individuals and society is multidimensional and interactive. For example, positive spirituality fosters active engagement in life, through religious and/or community activities, prayer, meditation, and other practices. In addition, the literature has found an association between spiritual and/or religious activities and the reduction in disability and disease, thus allowing seniors to remain actively engaged. 
There are several factors that influence successful aging. To achieve successful aging need to pay attention to several things, because there are many factors that influence. Successful elderly people are often identified as having a long life, but of course in addition to long life also has the characteristics of successful aging. From some opinions [19]. it can be concluded that the factors that influence successful aging are: having good physical mobility that is beneficial to him, high or adequate education, work that does not only rely on physical factors, active work or has activities positive, feeling optimistic and having self-efficacy, self-acceptance and accepting changes that occur, maturity of spirituality, having social support Papalia, Old, and[20] also said that social support from friends, especially from partners and children is a strong predictor of elderly health . In addition[21] stated that other factors that influence age, not smoking, health, social contact, physical activity, cognitive function, and have a life satisfaction.

Two basic principles of Javanese. There are two rules that determine the social and life patterns of Javanese society, namely the principles of rukun (harmony) and the principle of urmat (respect). The principle of rukun says that in every human situation it should behave in such a way that it does not cause conflict. The principle of harmony is intended to maintain society in a harmonious state. A harmonious state occurs when all parties are in a state of peace with one another, like to work together, accept each other, in a mood and agree. Rukun is an ideal condition that is expected to be maintained in all social relations, within families, in the community and in every permanent grouping. Everything that can interfere with the harmonious state and harmony in the family, environment, or society must be prevented[22]. The second rule, namely the principle of urmat, plays a large role in regulating patterns of interaction in Javanese society. Everyone in the way of talking and carrying themselves always has to show respect for others according to their degree and position. Fluency in implementing respect that is rightly developed in the Java community since childhood through education in families. According to Geertz, education is achieved through three feelings learned by Javanese in situations that demand respect, namely wedi, isin, and rila. Javanese feel that they cannot show proper respect to people who deserve respect. These three respectful attitudes will encourage individuals to always take respect. Javanese society is also expected to have the right inner attitude. One attitude as a sign of moral maturity, namely the Javanese should be patient. Patience means having a long breath in the awareness that in time the good naib will arrive. Other attitudes are nrima and iklas. Nrima means accepting all that we are watching, without protest and rebellion. Nrima means that even though people in a state of disappointment and difficulty must continue to react rationally, stay motivated, and do not resist what is experienced. A iklas attitude is a willingness to release one's own individuality and accept what has been determined. Rila is the ability to let go of what is owned with understanding[22].

\section{Methodology \\ 3.1 Design}

Based on the formulation of the problem in this study, the type of research used is descriptive qualitative research. Qualitative research is research related to ideas, perceptions, opinions, beliefs of the people to be studied and all of them cannot be measured by numbers[23];[24]. This is consistent with the purpose of this study, which is to explore the meaning of successful aging in the elderly. In qualitative research, the theory used is not forced to obtain a complete picture of a 
thing according to the views of participants who have been studied. But qualitative research still needs to use theory as a frame, as initial knowledge, as a provision for going to the research field. To get a complete picture of what is the purpose of this research, it is not by forcing to use certain theories but by searching, exploring and collecting data obtained in the field.

\subsection{Participants}

Participants in this study were 50 Javanese elderly who were willing to participate in the study by providing research data through interviews and observations. The determination of quantitative research participant technique uses purposive sampling or purposive sampling[25];[26]. To be able to get a participant that is in accordance with the characteristics specified, is done by contacting the authorities. In accordance with the purpose of the study, the characteristics of the participants were: elderly who lived at home with family, elderly who lived alone at home (not with children or family), elderly who lived in nursing homes, elderly with w with low social-economic status and who were still working. Another important characteristic is that the elderly who become participants are still able to communicate and are willing to be participants. Because the scope of the study was the province of Central Java, the participants were elderly who lived in the cities of Salatiga, Semarang, Magelang, Surakarta, Pekalongan, and Tegal. With these characteristics, as a preliminary study the number of participants in this study was 50 elderly with a variation of the four types of elderly.

\subsection{Data Collection and Analysis}

Data collection was conducted from May to August 2018. In this study, primary data sources were obtained from the elderly through interviews, direct observation and involvement of researchers. The data obtained in this study were analyzed using thematic analysis techniques[27];[23], namely by reducing, presenting data, and drawing conclusions, allowing researchers to find 'patterns' that were not clearly seen by others in stack of information obtained. Thematic analysis is the process of coding information, which can produce a list of themes, theme models or complex indicators, qualifications that are usually related to the theme, or things between or a combination of the indicators already mentioned. The validity of the data is done by interviewing the husband / wife, children, or relatives / people who live near the house with the participants, and for the elderly who live in the orphanage with their caregivers / nursing staff.

\section{Results and Discussion}

Description of participants data: 50 Javanese elderly in this qualitative study consisted of 35 female and 15 male, aged between 65-80 years, and according to predetermined criteria namely communicative and willing to be participants. Participants from six cities in Jawa tengah: Salatiga, Solo, Semarang, Magelang, Pekalongan, Tegal. Based on variations in types of elderly, participants included 25 elderly who lived at home with their children, 8 elderly who lived alone at own homes (not with children or family), 10 elderly who lived in nursing homes, and 7 elderly with low social-economic status and who were still working.

In accordance with the objectives of the study and based on data obtained from research, the results of the study showed that participants 'perceptions of successful aging varied because the 
participants' background conditions varied, the experiences experienced by participants also differed, as did the values adopted. But in general, participants' perceptions of successful aging include aspects related to family, physical health, adequate finance, social relations, and religious activities. Aspects related to families are considered important by participants because they feel happy and grateful if the family, especially children and grandchildren live in harmony, are economically well-off, and are successful or have a good job. It is an important and happy thing for Javanese parents (Koentjaraningrat, 1995) if their children are "mentas". in his old age, Javanese parents would be happy if their children were "mentas" which meant that their children had a family, got a good job, and had a good income. Another factor that influenced the existence of harmony and respect in the lives of Javanese people. Harmony in family life will always be pursued in the Javanese family, which has the effect of creating a sense of happiness. In addition to the respect that has been instilled since children, parents have a position that must be respected by their children. This condition influences the emergence of an attitude of respect for older people.

The results of this study are not much different from the results of Nguyen and Seal (2014). The purpose of their study was to define the definitions of successful aging according to Chinese and Chinese elders living in Milwaukee, WI. In-depth semi-structured interviews were conducted with 44 elders (Hmong $n=21$ and Chinese $n=23$ ). Findings show some similarities in the Chinese and Hmong elders' definitions although specific cultural differences exist. Chinese elders emphasized physical health and mobility, mental health, positive attitudes, shedding responsibilities, positive family relationships, financial stability, social engagement, religious faith, and accomplishments and volunteer work. Hmong elders emphasized physical health and mobility, mental health, harmonious relationships, positive family relationships, tangible family support, financial stability, social engagement, and religious faith.

For the elderly who live alone and who live in the nursing home, family factors are indeed a very important factor because participants who live alone say that they really want to stay often visited by their children and grandchildren or the participants themselves who visit their children and his grandson. But what is interesting is that even though they stated that they were happy if they could live with their families, some participants still felt grateful because they could still live in the nursing home, there were staff / caregivers who took care of and cared for their daily needs. Likewise for those who live alone, they remain grateful because what is important for them is that children and their families can live well and independently. This condition seems to be in accordance with the values of Javanese culture, namely nrimo and remain grateful in its current condition.

On the other hand there are participants who live alone even though they feel the condition, but still do not want to live with their children and grandchildren because the participants want their independent children and the participants themselves do not want to bother their children and still want to live in the community that is now occupied decades. Other participants stated that the difficulty was the place where the participants and their children lived far away, even though their economic conditions were also limited so they could not often see their children. If the child who has to look at the participant, the problem of actual costs is not too 
much of a problem but the problem is related to holidays or leave for children and grandchildren who certainly need regulation. Some participants who live alone often communicate with their grandchildren and other siblings and friends through their telephone.

For the elderly who live in nursing homes, there are participants who have never been visited by their children or family so often feel sad. Other participants stated that they were rarely visited by their children, usually children came only during holidays, therefore participants were very happy if there were visits from certain community groups to their nursing homes. For participants with low socioeconomic status who are still working, it also states that the attention of the family is very important. Some have not met their children and grandchildren for a long time because the place of residence is different from the island and the economic conditions of their children are also lacking. Likewise for participants who live together with their chidren/families, family factors are felt to be very important, because even though they often meet, participants want a harmonious, pleasant relationship, and there is effective communication between family members. From the opinions of these participants it can be concluded that successful elderly people are elderly who have close family ties or are cared for by the family. This is in accordance with what was stated by Geertz[28];[22], that existence harmony in the family is an important factor in the life of the Javanese. The principle of harmony is not only desired in family life, but also in relation to others. Harmony in the family is manifested by the family's conditions of mutual concern and the existence of a harmonious relationship between family members by not raising conflicts openly. In addition, participants also stated that successful seniors if their children succeed, especially having a position or job and education that is good and fulfilled in economic terms.

When it is related to the concepts of [17], the family aspect which is an important aspect of interpreting successful aging can be attributed to Rowe and Kahn's revision of successful aging concepts, namely the addition of the three characteristics previously stated[18], characteristics that is spirituality. Participants in this study are mostly active in religious activities that support the attainment of a level of spirituality, so that it also has an effect on the understanding that family is an important aspect that influences their opinions about successful aging. Elderly people who can maximize this function will support achieving successful aging. Elderly people who have a good spirituality function appear from having a sincere and sincere desire to improve the welfare of others and be able to reconcile and accept their own circumstances. Individuals who have a good level of spirituality will apply in the life of their families and will feel happy or have satisfaction if in their family life there is harmony and attention to each other.

\section{Conclusion}

The results showed that participants' opinions about successful aging included family aspects, physical health, adequate finance, social relations, and religious activities. With regard to the values of Javanese culture, the family aspect is an important matter to be considered. There are two rules that determine the social and life patterns of Javanese society, namely the principles of rukun (harmony) and the principle of urmat (respect). These two rules also affect how Javanese elderly interpret successful aging. The results of the study can be useful for the elderly, families, 
and the government as a basis for intervention in order to improve successful aging, especially in Central Java, which is a province or region that has many Javanese ethnic elderlies. By understanding the concept of a successful elderly based on the cultural values they have, researchers can develop model of interventions to promote successful aging for elderly more precisely and better.

\section{References}

[1] H. Orimo, H., \& Ito, "Reviewing the definition of elderly," J. Geriatr. Gerontol., vol. 6, no. 3, pp. 149-158, 2006.

[2] "Active Ageing: A Policy FrameWork. WHO. A Contribution of the World Health Organization to The Second United Nations World Assembly on Ageing. Madrid. Spain," World Health Organization, 2002. [Online]. Available: http://www.who.int.org. [Accessed: 12-Apr-2017].

[3] C. H. Nugraheni, M.. \& Soetjiningsih, Pengalaman kesepian pada lansia lansia dalam periode empty-rest. Universitas Kristen Satya Wacana, 2013.

[4] U. RI, "Undang-Undang Republik Indonesia No. 13 Tahun 1998 tentang Kesejahteraan Lanjut Usia,” 1998. [Online]. Available: http://www.bpkp.go.id/uu/filedownload/2/45/438. [Accessed: 06-Jun-2017].

[5] S. C.H, Psikogerontologi. Salatiga: Tisara Grafika, 2018.

[6] S. J.W, Life-Span Development: Perkembangan Masa Hidup. Dalas. McGraw-Hill: University of Texas, 2011.

[7] K. K. RI, "Pelayanan dan peningkatan kesehatan usia lanjut," Kementerian Kesehatan RI, Apr-2015. [Online]. Available: http://www.depkes.go.id/article/view/15052700010/pelayanan-dan-peningkatan-kesehatanusia-lanjut.html. [Accessed: 07-Apr-2017].

[8] P. D. dan I. K. K. RI, "Situasi lanjut usia (Lansia) di Indonesia," 2016. [Online]. Available: http://www.pusdatin.kemkes.go.id/pdf.php?id=16092300002.

[9] B. D.L, Duay \& V.C, "Senior adults' perceptions of successful aging," J. Educ. Gerontol., vol. 32, no. 6, pp. 423-445, 2006.

[10] R. Ferri, C., James, I., \& Pruchno, "Successful aging: Definitions and subjective assessment according to older adults," J. Clin. Gerontol., vol. 32, no. 4, pp. 379-388, 2009.

[11] T. M, "Understanding and theorizing the role of culture in the conceptualizations of successful aging and lifelong learning," J. Educ. Gerontol., vol. 40, no. 12, pp. 881-893, 2014.

[12] C. H. Riandana, H. \& Soetjiningsih, Psychological well-being pada lansia. Universitas Kristen SatyaWacana, 2014.

[13] B. U, Ecology of the family is a context for human development: Research perspectives. Developmental Psychology, 1986.

[14] E. Martin, P., Kelly, N., Kahana, B., \& Kahana, "Defining successful aging: A tangible orelusive concept," J. Gerontol., vol. 55, no. 1, pp. 14-55, 2015.

[15] H. R, Schulz., J, “A life span model of succsseful aging,” Am. Psychol., vol. 51, no. 7, pp. 
702-714, 1996.

[16] B. P.B, Successful aging: Perspectives from the behavioral sciences. New York: Cambridge University Press, 1993.

[17] K. J.W, Rowe \& R.L, "Successful aging," Gerontologist, vol. 37, no. 4, pp. 433-441, 1997.

[18] H. . Crowther, M.R., Parker, M.W., Achenbaum, W.A., Larimore, W.L., Koening, Rowe and Kahn's model of successful aging revisited: Positive spirituality- The Forgotten Factor. The Gerontologist, 2002.

[19] S. S.P, Psikologi usia lanjut, Cetakan Ke. Yogyakarta: University Press.

[20] R. T. Papalia, D. E., Old, S. W., \& Feldman, Human development. The McGraw Hill Companies, 2008.

[21] J. C.A, Depp, \& D.V, "Definitions and predictors of successful aging," America Journal of Geriatric Psychiatry, 2006.

[22] F. Magnis-Suseno, Etika jawa: Sebuah analisis falsafi tentang kebijaksanaan hidup Jawa. Jakarta: Gramedia, 1985.

[23] E. . Poerwandari, Pendekatan kualitatif dalam penelitian psikologi. Jakarta: Universitas Indonesia, 1998.

[24] Sugiyono, Memahami Penelitian Kualitatif. Bandung: CV Alfabeta.

[25] A. Suharsimi, Prosedur suatu penelitian: Pendekatan praktek. Jakarta: Penerbit Rineka Cipta, 2002.

[26] L. . Moleong, Metodologi kualitatif. Bandung: PT Remaja Rosdakarya, 2012.

[27] Z. J.J, Shaughnessy., E.B, Zechmeister., J.S, Research Methods in Psychology, Ninth Edit. New York: McGraw-Hill, 2012.

[28] Koentjaraningrat, Pengantar ilmu antropologi. Jakarta: Aksara Baru, 1985. 